\title{
ASSESSMENT OF THE FLUORIDE CONCENTRATION AND pH IN DIFFERENT MOUTHRINSES ON THE BRAZILIAN MARKET
}

\author{
AVALIAÇÃO DO TEOR DE FLÚOR E PH EM DIFERENTES SOLUÇÕES PARA \\ BOCHECHOS NO MERCADO NACIONAL
}

\author{
Alberto Carlos Botazzo DELBEM \\ Assistant PhD Professor of the Discipline of Pediatric Dentistry of the Department of Pediatric and Social Dentistry of Araçatuba Dental \\ School - UNESP. \\ Kikue Takebayashi SASSAKI \\ Assistant PhD Professor of the Discipline of Biochemistry of the Department of Basic Sciences of Araçatuba Dental School - UNESP. \\ Alessandra Maia de CASTRO \\ Leila Maria Cesário Pereira PINTO \\ Maurício BERGAMASCHI \\ Post Graduation students at the Doctorate level in Pediatric Dentistry of Araçatuba Dental School - UNESP.
}

\begin{abstract}
Tn this study, the fluoride concentration and $\mathrm{pH}$ of 14 commercial brands of mouthrinses were assessed in order to compare them with the values expressed on the labels and with those established by the National Sanitary Surveillance Agency. Forty-two (42) products were obtained from three places, with different manufacturing batches. The fluoride concentration was determined in diluted solutions, using a combined specific electrode for fluoride ion (9609 BN Orion Research) and ion analyzer (290 A Orion Research). The results showed that 50\% of the solutions had statistically significant differences, with higher fluoride concentrations than those expressed on the labels, and the $\mathrm{pH}$ ranged from 4.23 to 7.34, but only one of the products registered the $\mathrm{pH}$ value on its label.
\end{abstract}

UNITERMS: Topical fluorides; Sodium fluoride; Dental caries.

\section{INTRODUCTION}

The role of fluoride as one of the fundamental elements in the control and prevention of dental caries has been emphasized since the 1940's. However, with the introduction of topical fluoridated products for clinical application, subtle but significant alterations have occurred with regard to the most efficient way of using these materials (Heath, et al. ${ }^{6}$ 2001).

Fluoride applied in a topical form is most effective in controlling dental caries than that acquired pre-eruptively (Rölla, et al. ${ }^{16}$ 1995), mainly when products are used with concentrations over $100 \mathrm{ppm} \mathrm{F}$, propitiating the incorporation of fluoride to the enamel surface in the form of calcium fluoride, which acts as a reservoir for the slow fluoride release (Villena, Cury $^{18}$, 1998).

According to Marinho, et al. ${ }^{10}$ (2002) the term "topically applied fluoride" is employed to describe the methods that release this agent to the exposed dental surfaces, causing a local protector effect and which therefore is not meant to be ingested.

Mellberg ${ }^{11}$ (1990); Di Nicoló, et al. ${ }^{5}$ (1997) make a distinction between the topical methods: those for professional use (highly concentrated solutions, gels and varnishes) and those for home use (dentifrices and less concentrated solutions).

The use of fluoride rinses is an additional measure of protection against caries in adults and children. As regards the advantages of this method, Adair ${ }^{1}$ (1998) emphasizes the stability of formulations (except for stannous fluoride, according to Mellberg $\left.{ }^{11}, 1990\right)$, the pleasant taste, absence of gum irritation and tooth staining, simplicity of use and low cost. However, $\mathrm{Cury}^{4}$ (2000) reported that the efficiency of this method depends on the degree of compliance of the patient, and the difficulty of establishing a new habit will demand ability from the professional.

According to Stookey ${ }^{17}$ (1994), mouthrinses with fluoridated solutions were originally proposed for public health programs carried out in schools for daily application $(0.05 \%$ sodium fluoride solution) and weekly or fortnightly 
( $0.2 \%$ sodium fluoride solution). Doubts arose about the effectiveness of this method in the early 1980's, due to the decline in caries, attributed mainly to the use of fluoridated dentifrices (Ripa $\left.{ }^{15}, 1991\right)$. Currently, fluoridated solutions are indicated for patients at high risk and with caries activity, who may benefit from this method. This category includes those with active carious lesions, deficient oral hygiene, users of orthodontic devices or prostheses, patients with exposed root surfaces, individuals under chemotherapy or radiotherapy treatment, and patients with decreased salivary flow (Adair ${ }^{1}$, 1998; Kumar, Green ${ }^{8}$, 1998; Heath, et al. ${ }^{6}$, 2001).

The application of fluoridated rinses is not recommended for preschool children, who do not have complete control over the swallowing reflexes and swallow about $20-25 \%$ of the total volume of the solution. The amount of fluoride swallowed ranges from $0.24-0.44 \mathrm{mg}$ and depends on the volume of the solution, duration of the mouthrinse and the child's age (Stookey $\left.{ }^{17}, 1994\right)$.

Data have identified fluoridated solutions as a risk factor for dental fluorosis (Osuji, et al. ${ }^{13}$ 1988); however, this observation is surprising, since fluorosis is related to the ingestion of excessive and constant doses of fluoride before 7 years of age, while mouthrinses are indicated for use after this age (Stookey $\left.{ }^{17}, 1994\right)$.

According to Newbrun ${ }^{12}$ (1992) fluoridated rinses were approved by the FDA (Food and Drug Administration) in 1974 and accepted by the CDT (Council Dental Therapeutics) in the following year. These products are available in the following concentrations: $0.05 \%$ sodium fluoride solution for daily use and $0.2 \%$ for weekly or fortnightly use. Neutral solutions containing $0.02 \%$ sodium fluoride were also approved by the FDA, but the main solutions sold without the need of prescription are those containing $0.05 \%$ sodium fluoride (Winston, Bhaskar ${ }^{20}$, 1998).

Pierobon, et al. ${ }^{14}$ (1999) assessed the concentration and effectiveness of six sodium fluoride solutions prepared by dispensing pharmacies and observed significant differences in the fluoride concentration and reactivity of the products.

According to Heath, et al. ${ }^{6}$ (2001), with the increasing use of solutions, gels and varnishes, it is necessary to assure that the risk of chronic intoxication is not increased. Thus the clinician must be aware of the dose, the rates relative to fluoride retention in saliva, risk of ingestion and toxicity of the fluoridated compounds used in clinics or at home, so that the fluoride use may be safe and effective.

Based on the assumption that fluoridated solutions used for mouthrinses are efficient and are an important instrument for caries prevention, the object of this study was to assess the concentration of fluoride and the $\mathrm{pH}$ of different mouthrinses sold on the Brazilian market, in order to compare the values obtained with the values expressed on the product labels, as well as with those established by the National Sanitary Surveillance Agency (ANVISA ${ }^{2}$ in 2000)

\section{MATERIAL AND METHODS}

Mouthrinses were acquired in drugstores, supermarkets and dental products trade establishments (Table 1). Three products were acquired from each brand, of different manufacturing batches, purchased in the following places: Lins (SP), Londrina (PR) and Uberlândia (MG), adding up to 42 products.

The solutions were coded from 1 to 42 , and $1 \mathrm{~mL}$ of each product was placed by pipette into a $100-\mathrm{mL}$ volumetric flask and the volume was made up with deionized water, obtaining three dilutions for each product. Afterwards, two (2) 1-mL samples were removed from each dilution and put into plastic flasks (J-10, Injeplast) totalizing six samples of each product. The fluoride analysis was performed by means of a combined specific electrode for fluoride ion $9609 \mathrm{BN}$ (Orion Research) and ion analyzer 290 A (Orion Research). A calibration curve was initially made, which ranged from 0.5 to $8.0 \mathrm{ppm} F$ for calculation of the concentration in ppm $\mathrm{F}$. The fluoride in the solutions was determined after mixing $1 \mathrm{~mL}$ of the diluted sample with $1 \mathrm{~mL}$ of TISAB II (buffer acetate $0.75 \mathrm{M}, \mathrm{pH} 5.0, \mathrm{NaCl} 1.0 \mathrm{M}$ and CDTAdiaminocyclo-hexane-tetra-acetic acid $0.4 \%$ ), under light and constant agitation. A new calibration curve was obtained after every 30 readings, and the electrode was washed with deionized water and dried with absorbent paper between readings. The results were shown directly on the ion analyzer display in millivolts, awaiting stabilization, which varied according to the fluoride concentration of the sample. The data obtained were converted into ppm of fluoride.

The $\mathrm{pH}$ was determined through the electrometric method by means of the apparatus $p H$ Meter TEC-2 (Tecnal), which was calibrated with a standard solution $-\mathrm{pH}$ 7.0. After homogenization (magnetic agitator), $5 \mathrm{~mL}$ of each solution was placed in a beaker and the $\mathrm{pH}$ reading took 5 minutes after the value was stabilized. The electrode was washed with deionized water and dried with absorbent paper at each product change.

Statistical analysis comprised variance analysis (ANOVA) and the Tukey Test $(\mathrm{p}<0.05)$.

\section{RESULTS}

The labels of the fluoridated solutions found on the Brazilian market indicated $0.05 \%$ sodium fluoride $(226 \mathrm{ppm}$ F), but one of the brands showed a formulation of $0.05 \%$ fluoride ions, which corresponds to $500 \mathrm{ppm} \mathrm{F}$. The fluoride concentration of the products analyzed ranged from 224.7 to $567.3 \mathrm{ppm} F$ and rarely coincided with the value on the label, as $50 \%$ of the solutions showed statistically significant differences, with concentrations above those specified (Table $1)$.

The $\mathrm{pH}$ analysis revealed solutions with $\mathrm{pH}$ ranging between 4.23 and 7.34 (Table 1); however only one of the commercial brands registered the $\mathrm{pH}$ value on its package. 


\section{DISCUSSION}

According to the National Sanitary Surveillance Agency (Agência Nacional de Vigilância Sanitária) ANVISA ${ }^{2}$ (2000), the solutions called oral mouthrinses belong to a category of products for dental and oral hygiene. According to Resolution RDC 79, issued on August $28^{\text {th }} 2000$, in Appendix VII, mandatory items on the product package are stated as being the product name and group/type to which it belongs (if this is not implicit in the name), brand, number of the record/resolution, lot or batch, expiry date (month/ year), content, country of origin, manufacturer/importer, manufacturer/importer domicile, manner of use, warnings/ restrictions on use, composition/ingredients, inscription in the National Corporate Tax Register (CNPJ) and purpose of the product (when not implicit in the name). Furthermore, in Item D of this appendix on the labels of oral mouthrinses, the following must specifically be stated: name of the fluoride compound used, its concentration expressed in ppm (parts per million), the manner of use and the counterindications for children below 6 years of age.

With regard to the risk arising from improper or accidental use, it was observed that only 4 of the 14 brands gave this information and only one product did not contain the specific instruction with regard to use by children under the age of 6 .
Newbrun $^{12}$ (1992) stated that all packages should contain legible instructions on their labels, clearly informing the user to expectorate the solution after mouthrinsing to avoid swallowing. Like all active pharmacological elements, the fluoride swallowed in high concentrations may cause undesirable effects, although the incidence of acute intoxication by fluoride through mouthrinses is low.

The average concentrations of fluoride in solutions ranged from 224.7 to $567.4 \mathrm{ppm} F$ (Table 1) and showed significant statistical differences in relation to the value specified on the label, as $50 \%$ of the solutions showed a higher concentration than that expressed. Of the 14 commercial brands analyzed, three mouthrinses, S3, S7 and $\mathrm{S} 12$, exceeded the maximum fluoride concentration set by ANVISA $^{2}$ (2000), which should be between 202.5 and 247.5 ppm F. The fluoride concentration of S3 and S12 were not so higher than that set by ANVISA, but S7 exhibits the double value.

Another surprising data was the fact that the label of one brand (S7) showed a formulation of $0.05 \%$ fluoride ions for daily mouthrinses, which is not the recommended concentration (Newbrun ${ }^{12}$, 1992; Winston, Bhaskar ${ }^{20}, 1998$ ). Furthermore, according to ANVISA ${ }^{2}$ (2000) the fluoride concentration should be expressed in ppm on the package, therefore greater attention should be paid to what is specified on the product package, as solutions with $0.05 \%$ fluoride

TABLE 1- Comparison between the means of fluoride concentrations (ppm) and mean $\mathrm{pH}$ Value of fluoridated mouthrinses with the values expressed on the labels $\left(n=6^{* *}\right)$

\section{Solutions}

\begin{tabular}{|c|c|c|c|c|}
\hline & \multicolumn{2}{|c|}{ Fluoride } & \multicolumn{2}{|c|}{ pH } \\
\hline & Means \pm S.D. ${ }^{*}$ & Label & Means & Label \\
\hline S1 (Oral B) & $225.5 \pm 20.1 \mathrm{a}$ & $226.0 \mathrm{a}$ & 5.62 & - \\
\hline S2 (Fluorsol) & $225.3 \pm 5.2 \mathrm{a}$ & $225.0 \mathrm{a}$ & 6.75 & - \\
\hline S3 (Fluordent- Turma da Mônica) & ${ }^{* * *} 247.8 \pm 7.5 \mathrm{a}$ & $226.0 \mathrm{~b}$ & 5.48 & - \\
\hline S4 (Cepacol Flúor) & $226.3 \pm 4.9 \mathrm{a}$ & $226.0 \mathrm{a}$ & 7.34 & - \\
\hline S5 (Cepacol Júnior) & $226.3 \pm 3.6 a$ & $226.0 \mathrm{a}$ & 6.92 & - \\
\hline S6 (Colgate Plax Kids) & $227.3 \pm 9.2 \mathrm{a}$ & $225.0 \mathrm{a}$ & 4.63 & - \\
\hline S7 (Fluorstesin) & ${ }^{* * \star} 567.4 \pm 16.7 \mathrm{a}$ & $500.0 \mathrm{~b}$ & 5.55 & - \\
\hline S8 (Colgate Plax) & $226.8 \pm 4.2 \mathrm{a}$ & $225.0 \mathrm{a}$ & 6.89 & - \\
\hline S9 (Kolynos Flúor) & $235.3 \pm 7.7 a$ & $227.0 \mathrm{~b}$ & 6.51 & - \\
\hline S10 (Sorriso Herbal) & $224.7 \pm 7.0 \mathrm{a}$ & $228.0 \mathrm{a}$ & 6.54 & - \\
\hline S11 (Fluotrat) & $236.6 \pm 5.0 \mathrm{a}$ & $226.0 \mathrm{~b}$ & 5.47 & - \\
\hline S12 (Fluordent Reach) & ${ }^{* \star *} 248.2 \pm 6.7 \mathrm{a}$ & $226.0 \mathrm{~b}$ & 6.90 & - \\
\hline S13 (Reach ER) & $246.3 \pm 5.0 \mathrm{a}$ & $226.0 \mathrm{~b}$ & 7.00 & - \\
\hline S14 (Fluorgard) & $231.8 \pm 9.7 \mathrm{a}$ & $225.0 \mathrm{~b}$ & 4.23 & 4.00 \\
\hline
\end{tabular}

The mean fluoride concentrations obtained and the values expressed on the labels of each solution followed by different letters differ statistically to the level of $5 \%$.

* S.D. = Standard Deviation. ${ }^{* *}$ Numbers of repeated analyses. ${ }^{* \star *}$ Values above the maximum limit established by ANVISA ${ }^{2}$ (2000). 
ions have $500 \mathrm{ppm} \mathrm{F}$, differing from those with $0.05 \%$ of sodium fluoride, which have 226 ppm F (Whitford ${ }^{19}$, 1987).

Considering that the minimum dose capable of causing toxic signs and symptoms requiring immediate therapeutic intervention is $5 \mathrm{mg} \mathrm{F} / \mathrm{Kg}$ of body weight (Whitford ${ }^{19}$, 1987), the accidental ingestion of a product with a greater concentration would increase the risk of acute reaction. Normally, $10 \mathrm{~mL}$ of solution are used for mouthrinsing (Ripa ${ }^{15}$, 1991; Maltz, Wannmacher ${ }^{9}, 1995$; Adair ${ }^{1}, 1998 ;$ ANVISA $^{2}, 2000$;); thus, mouthrinses with solutions of $0.05 \%$ sodium fluoride have $2.26 \mathrm{mg}$ of fluoride in $10 \mathrm{~mL}$, an amount far from the probably toxic dose, also for lower age brackets. On the other hand, the commercial brand with $0.05 \%$ fluoride ions for this same volume has $5 \mathrm{mg}$ fluoride ions, consequently care must be taken with the use of this product, as the ingestion of $200 \mathrm{~mL}$ would be a probably toxic dose for a $20-\mathrm{Kg}$ child. The Council Dental Therapeutics (CDT) of the American Dental Association (ADA) establishes the maximum value of $120 \mathrm{mg}$ of fluoride ions for a flask of solution, however, the product analyzed containing $0.05 \%$ of fluoride ions was bottled in flasks with a capacity of $500 \mathrm{~mL}$, containing an amount of $250 \mathrm{mg}$ of fluoride ions above that allowed by the $C D T$ (Whitford ${ }^{19}, 1987$ ).

The $\mathrm{pH}$ of the 14 products analyzed ranged from 4.23 to 7.34 and only one of them indicated the $\mathrm{pH}$ value on the label (Table 2), which was considered acidic according to the analysis performed $(\mathrm{pH}=4.23)$. For Mellberg ${ }^{11}(1990)$, lowering the $\mathrm{pH}$ in topical fluoride preparations results in an increase in the calcium fluoride deposition in sound enamel, but not in etched enamel. Heimer, $\mathrm{Cruz}^{7}$ (1995) found that after topical application of four fluoridated solutions, showing neutral and acid $\mathrm{pH}$, on the human dental enamel surface in vitro, the amount of calcium fluoride deposited was extremely reduced, irrespective of the $\mathrm{pH}$ of the solution, suggesting the interference of other components in the products. According to Barkvoll, et al. ${ }^{3}$ (1988) many products currently used in oral hygiene contain lauryl sodium sulfate as a synthetic detergent, but this component reduced the deposition of calcium fluoride, probably by increasing the solubility of this compound in water.

Although the incidence of acute intoxication is low, mainly if care in administration is taken, adequate instruction for home use and the assessment of the real need of additional sources of fluoridated products should be intensified, especially because these products are sold without requiring a prescription. In the face of the massive introduction of fluoridated mouthrinses on the market, the need for packages to have labels with pertinent recommendations and the difficult use by children must be emphasized (Maltz, Wannmacher ${ }^{9}, 1995$ ).

Furthermore, when indicating fluoridated mouthrinses, the professional should know what the specifications on product labels are, in order to identify the concentration and amount of fluoride present.

\section{CONCLUSION}

The fluoridated solutions analyzed showed a fluoride concentration similar to or higher than that specified on the label.

Of the 14 brands analyzed, three products (S3, S7 and S12) exceeded the limit established by ANVISA (202,5247,5 ppm F).

The $\mathrm{pH}$ in fluoridated solutions ranged from 4.23 to 7.34 , but only one brand specified this value on its label.

\section{RESUMO}

No presente estudo, o teor de flúor e o $\mathrm{pH}$ de 14 marcas comerciais de soluções para bochechos foram avaliados a fim de comparar com os valores expressos nos rótulos e com aqueles determinados pela Agência Nacional de Vigilância Sanitária. Foram adquiridos 42 produtos em três localidades, com diferentes lotes de fabricação. A concentração de flúor foi determinada em soluções diluídas, utilizando-se eletrodo específico combinado para íon flúor (9609 BN Orion Research) e analisador de íons (290 A Orion Research). Os resultados mostraram que 50\% das soluções apresentaram diferenças estatisticamente significantes, com concentrações de flúor superiores àquelas expressas nos rótulos e o $\mathrm{pH}$ variou entre 4,23 a 7,34, mas apenas um dos produtos registrou o valor do $\mathrm{pH}$ em seu rótulo.

UNITERMOS: Fluoretos tópicos; Fluoreto de sódio; Cárie dentária.

\section{REFERENCES}

1- Adair SM. The role of mouth rinses in the control of dental caries: a brief review. Pediatr Dent 1998; 20:101-4.

2- Agência Nacional de Vigilância Sanitária (ANVISA). Resolução RDC n. 79, ago 2000.

3- Barkvoll P, Rölla G, Lagerlöf F. Effect of sodium lauryl sulfate on the deposition of alkali-soluble fluoride on enamel in vitro. Caries Res 1988; 22:139-44.

4- Cury JA. Uso do flúor e controle da cárie como doença. In: Baratieri, LN. Odontologia restauradora: fundamentos e possibilidades. São Paulo: Artes Médicas, 1992. p.33-68.

5- Di Nicoló R, Myaki SI, Long SM, Rocha RG. Prevenção em odontopediatria: fluoretos, conceitos atuais e tendências futuras. Rev Bras Odontol 1997; 54:163-6.

6- Heath K, Singh V, Logan F, Mcintyre J. Analysis of fluoride levels retained intraorally or ingested following routine clinical applications of topical fluoride products. Aust Dent J 2001; 46:2431 .

7- Heimer MV, Cruz RA. A deposição de fluoreto de cálcio no esmalte dentário humano in vitro após tratamento com soluções fluoretadas para bochechos. Rev Bras Odontol 1995; 52:9-14. 
8- Kumar JV, Green EL. Recommendations for fluoride use in children. NY State Dental J 1998; 64:40-7.

9- Maltz M, Wannmacher F. Fluoretos como medicamentos. In: Wannmacher L, Ferreira MBC. Farmacologia clínica para dentistas. Rio de Janeiro: Guanabara Koogan, 1995. p.182-93.

10- Marinho VCC, Higgins JPT, Sheiham A, Logan S. Fluoride rinses for preventing dental caries in children and adolescents (protocol for a Cochrane Review). In: The Cochrane Library, 4 2002. Oxford: Update Software.

11- Mellberg JR. Evaluation of topical fluoride preparations. J Dent Res 1990; 69:771-9.

12- Newbrun E. Current regulations and recommendations concerning water fluoridation, fluoride supplements, and topical fluoride agents. J Dent Res 1992; 71:1255-65.

13- Osuji OD, Leake JL, Chipman ML, Mikiforuk G, Locker D, Levine N. Risk factors for dental fluorosis in a fluoridated community. J Dent Res 1988; 130:1488-92.

14- Pierobon CN, Tabachoury CM, Cury JA. Avaliação de bochechos fluoretados preparados por farmácias de manipulação. Anais da $16^{\mathrm{a}}$ Reunião Anual da Sociedade Brasileira de Pesquisa Odontológica Brasileira-SBPqO; 1999 set 8-11; Águas de São Pedro (SP). São Paulo: SBPqO; 1999. p.123, resumo B088.

15- Ripa LW. A critique of topical fluoride methods (dentifrices, mouthrinses, operator, and self-applied gels) in era of decreased caries and incresead fluorosis prevalence. J Public Health Dent $1991 ; 51: 23-41$.

16- Rölla G, Holund U, Koch G. Cáries dentárias: prevenção. In: Koch G. Odontopediatria: uma abordagem clínica. 2.ed. São Paulo: Ed. Santos, 1995. p.117-42.

17- Stookey GK. Review of fluorosis risk of self-applied topical fluorides: dentifrices, mouthrinses and gels. Community Dent Oral Epidemiol 1994; 22:181-6.

18- Villena RS, Cury, JA. Flúor: aplicação sistêmica. In: Corrêa MSNP. Odontopediatria na primeira infância. São Paulo: Ed. Santos, 1998. p.291-314.

19- Whitford GM. Fluoride in dental products: safety considerations. J Dent Res 1987; 66:1056-60.

20- Winston AE, Bhaskar SN. Caries prevention in the 21st century. J Am Dent Assoc 1998; 129:1579-87.
Recebido para publicação em: 03/06/2003

Enviado para reformulações em: 05/08/2003

Pronto para publicação em: 21/08/2003

Address for Correspondence:

Prof. Dr. Alberto Carlos Botazzo Delbem

UNESP- Faculdade de Odontologia de Araçatuba

Disciplina de Odontopediatria

Rua José Bonifácio, 1193

Bairro Vila Mendonça

Araçatuba - SP CEP:16015-050

Fone:0XX-18-620-3235

e-mail: adelbem@foa.unesp.br 